\title{
Participatory Mapping of Terrestrial Fishery Resources in Kwale District, Kenya
}

\author{
Patrick Kimani and David Obura \\ CORDIO East Africa, P.O. Box 10135 Mombasa 80101, Kenya
}

\begin{abstract}
Key words: participatory mapping, PRA, coral reefs, artisanal fisheries, resource access, Diani, Kenya
\end{abstract}

\begin{abstract}
A participatory mapping study was conducted in Kinondo location of Kwale district in Kenya. The area is subject to high human population and development pressure in the north, where tourism and urban development is intense, compared to lower population pressure in the south where such development is low. Our focus was to document information about these resources that have maintained fishing for many generations and to address issues of their conservation and management. The study focused on the spatial arrangement, access, ownership and use of land-based resources, mainly shrubs, grasses and trees, at four landing sites along the north-south population gradient. Participatory techniques (sketch maps, livelihood diagrams and transect walks) were applied, where trained fishers led other fishers in mapping, and the local Digo language was used for recording names. Resources were arranged in distinct vegetation zones parallel to the beach. A north-south increase in resource availability and abundance was recorded, inversely related to the higher population pressure in the north compared to the south. While much of the land on which vegetation resources are located was publicly accessible, a significant part is owned by absentee landlords, concentrated in the north. This over time results in increasingly restricted access to resources by fishermen, as shown in the more developed, northern section of the study site. Fishers also experience problems with access routes to landing sites on the beach due to encroachment on routes by beachfront development. The mapping activity revealed the potential for conflict over resource access and the need for solutions to maintain fishers' access to terrestrial resources important for fishing.
\end{abstract}

\section{INTRODUCTION}

The management of coastal natural resources is especially difficult, in part because of the complexity and sensitivity of both the coastal terrestrial and marine environment (King, 2000). A first step towards sustainable resource management is an understanding of the sites and usage patterns (Arquiza, 1999). Baseline data is necessary for resource management and for tracking changes in the resource base (Ford et al., 1998), and using participatory approaches facilitates later resource management (Chapi et al.,
2001, Obura et al., 2002b). While legislation by the Kenya Environmental Management and Coordination Act of 1999 includes specific management actions for the coastal environment, with guidelines on marine resources, marshes and mangroves (Wamukoya et al., 2000), terrestrial resources used in fishing are not mentioned.

Spatial information about terrestrial resources used in fishing is important since all traditional fishing gears are made using some level of local natural resources. In the Diani-Chale area of Kenya, participatory mapping and indigenous knowledge have been documented for coral reef 
areas (Obura \& Mwaura 2001, Obura \& Wanyoni 2001), but not for the terrestrial access routes and resources used in making fishing gear. Other studies have documented that resources are extracted from forests for use by fishermen (Glaesel, 1997; King, 2000), but have not specified their precise locations.

This study was conducted to document and fill gaps of information about terrestrial fishery resources through mapping, by investigating: a) the resources and their uses in the making of fishing gear and accompanying tools, b) the spatial arrangement of resources, c) access routes to resources and landing sites, and d) issues arising, such as conflict zones. The study was constructed to compare resource availability along a northsouth gradient to determine how other land uses related to development in the north affect fishing activity.

\section{MATERIALS AND METHODS}

Galu and Kinondo sub-locations form the southern portion of the Diani-Chale area, (approximately $4^{\circ} \mathrm{S}$ ) in Kwale district, $20 \mathrm{~km}$ south of Mombasa, Kenya (Fig. 1). The study focused on the four fish landing sites of Mwaepe, Mvuleni, Mwanyaza (in Galu) and Kinondo-Chale (in Kinondo). Sampling further north in Diani was not possible at the time of the study.

Inland, the natural habitat consists of expansive grassland, bush-land and tropical lowland

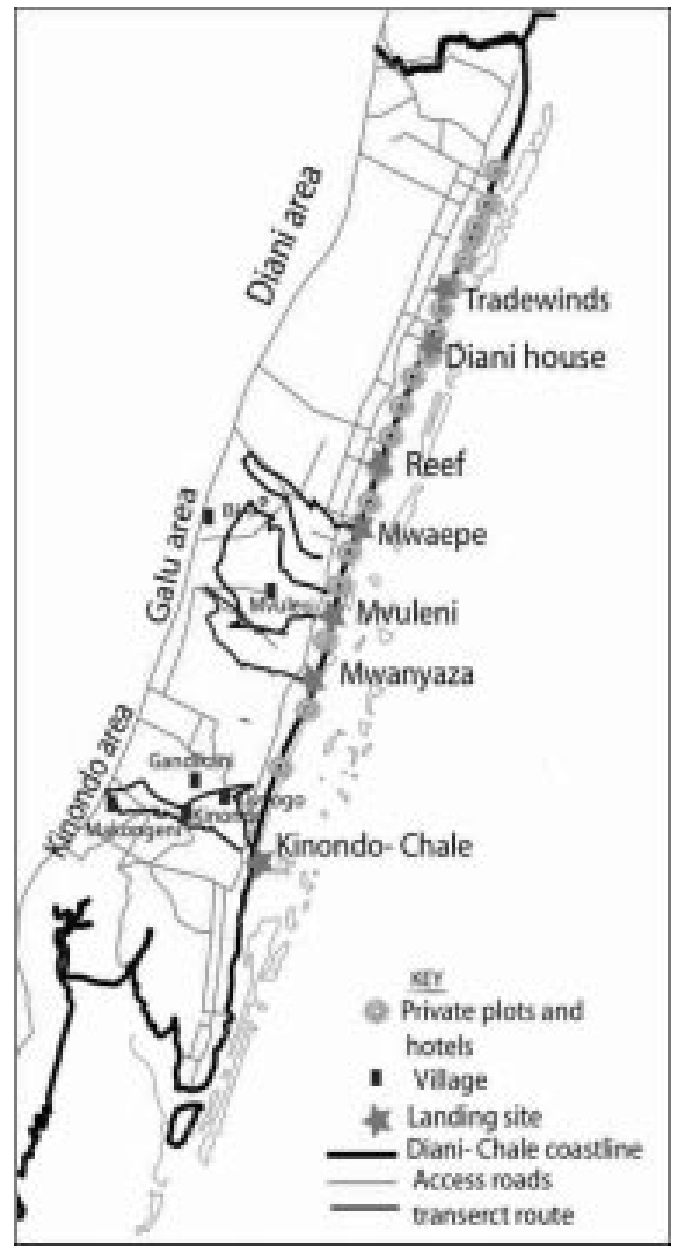

Fig. 1. Map of the Diani-Chale area, showing the 4 landing sites on Diani beach, namely Maepe, Mvuleni, Mwanyanza and Kinondo-Chale

Table 1. Basic vegetation and land use zonation of Kinondo. Zonation is based on historical land-use, present vegetation type and beach area gazettment. The density of vegetation in each zone is estimated in subjective classes of low, sparse, moderate and high density

\begin{tabular}{|c|c|c|c|c|}
\hline Zone & Type of locality & $\begin{array}{l}\text { Primary } \\
\text { vegetation }\end{array}$ & $\begin{array}{l}\text { Vegetation } \\
\text { density }\end{array}$ & Land use \\
\hline 1 & $\begin{array}{l}\text { (a) Beach area } 1 \\
\text { (b) Beach area } 2\end{array}$ & $\begin{array}{l}\text { Primarily forest } \\
\text { Forest transition to shrubs }\end{array}$ & $\begin{array}{l}\text { High } \\
\text { moderate }\end{array}$ & $\begin{array}{l}\text { Tourism; private cottages and hotels } \\
\text { Settlement; private cottages and } \\
\text { residential houses }\end{array}$ \\
\hline 2 & $\begin{array}{l}\text { (a) Beach area } 3 \\
\text { (b) Beach area } 4\end{array}$ & $\begin{array}{l}\text { Shrubs } \\
\text { Shrubs }\end{array}$ & $\begin{array}{l}\text { sparse } \\
\text { sparse }\end{array}$ & $\begin{array}{l}\text { Settlement; private cottages and } \\
\text { residential houses } \\
\text { Settlement; private cottages and } \\
\text { residential houses }\end{array}$ \\
\hline 3 & Grasslands & Grasses & Low & $\begin{array}{l}\text { Limited farming and few community } \\
\text { settlements }\end{array}$ \\
\hline 4 & $\begin{array}{l}\text { Farmland and } \\
\text { homesteads }\end{array}$ & Farm crops & Low & $\begin{array}{l}\text { Populated community settlements and } \\
\text { farmland }\end{array}$ \\
\hline
\end{tabular}


woodland interspersed with protected traditional sacred sites known as Kayas (King, 2000) the remnants of forests that once covered the entire area. However, much of the woodland and bush was cleared, inland for agriculture and, closer to the beach, for tourism. Tenure of most of the land is not guaranteed under title deeds, and is under customary or community ownership. The study area is divided into distinct vegetation zones running approximately parallel to the beach, as a result of modification by land use activities, and is used descriptively by fishermen (Table 1). The zonation is based on natural vegetation and historic land use patterns, including village location, farming activities as well as government gazettement of beach plots and access routes.

The mapping methodology was designed by combining techniques from Participatory Rural Appraisal (PRA) (Lelo et al., 2001) and Participatory Coastal Resource Assessment (PCRA) guidelines (Walters et al., 1998). Three PRA tools were selected: sketch mapping, livelihood mapping and transecting. They were specifically used in combination because they are easily applied in the field and complement each other. Assistants were selected by community elders and given four days training to facilitate mapping with the fishers. At each landing site, ten fishers representative of different gear types were nominated to conduct the mapping activity, which was conducted in a focus group setting.

Fishers were asked to give an inventory of terrestrial resources used and why they prefer their use. Names of resources were given in the local Digo language. Sketch maps were made on the ground with resources represented by objects such as stones, shells, sticks and leaves. The trained mapping assistants then translated these to paper maps which were combined into larger charts. The relative density of the overall vegetation resources in each zone was assessed qualitatively by the authors following analysis of the maps and discussions during the mapping activities. A four point scale was used: high, moderate, sparse and low density. This scale was used to give an approximate indication of the level of resources available to fishers in each zone.

Circular livelihood diagrams were drawn alongside sketch maps on the ground and fishers were asked to indicate where they obtain their fishing resources within the local geographic area. Representative objects earlier used in mapping were again used. The boundary categories were defined as either inside, outside or partly inside/ partly outside the boundary of their local area.

Transect walks were conducted to verify the information provided in sketch maps, and facilitate collection of additional information not reflected in initial maps such as resource ownership and access issues. Routes were selected from the sketch maps to ensure that they passed through resourcerich areas commonly used by fishers. All transects were out-and-return routes, starting at the beach landing sites, moving inland to the boundary of zone 4 , then returning to the beach by an alternate route. They were thus irregular in shape (see Fig. 1), but comparable due to the consistent vegetation zonation of the area. Data were recorded on a sheet, and locations determined using a geographical positioning system (GPS).

\section{RESULTS}

The primary fishing gears used in the study area are basket traps, hand spears, spearguns, handlines, bottom set nets and the gill nets. Local resources for making these gears and their accompanying tools fall in two major categories: a) trees for making canoes and b) shrubs and reeds used in making gears and other tools (Tables $2 \& 3$ ). Trees are found either on farmland, forests or isolated in bush-land, reeds are found in the grasslands and shrubs are found in bush-lands or in forest patches. Most gears rely on more than one type of resource for construction, likewise most resources are used to assemble multiple gears, and hence are in more demand than others (Table 3 ). Resources obtained outside of the community area are for nontraditional gears (steel hooks and fishing twine), or for new materials superior to traditional materials (nylon nets and fishing twine).

\section{Spatial resource distribution}

The resource maps show the general arrangement of resources in all the areas, across the profile from the beach up to areas adjacent to villages, however with a varied configuration amongst the different 
Table 2. Inventory of canoe making trees in Kinondo location

\begin{tabular}{llll}
\hline Local name of tree & Scientific name & Reasons for preferred use & Status of resource \\
\hline M'nyala & Cussonia zimmermanni & Easily floats in water & $\begin{array}{c}\text { Rare and less used; only found in } \\
\text { Chale area }\end{array}$ \\
Mzambarau & Syzygiumcuminii & Easily floats in water & $\begin{array}{c}\text { Rare and rarely used; found in } \\
\text { Chale area }\end{array}$ \\
Mnywamaji & Trichilia emetica & Easily floats in water & $\begin{array}{c}\text { Rare and rarely used; only found in } \\
\text { Chale area }\end{array}$ \\
Mkungu & Terminalia catapaa & Easily floats in water & $\begin{array}{c}\text { Rare and rarely used; only found in } \\
\text { Chale area }\end{array}$ \\
Miembe (mango) & Mangifera indica & $\begin{array}{l}\text { Lasts longer than most } \\
\text { alternative trees }\end{array}$ & $\begin{array}{c}\text { Grows faster than the other trees; } \\
\text { under pressure; also used for food } \\
\text { Mchusa }\end{array}$ \\
(not yet identified) & Easily floats in water & $\begin{array}{c}\text { Rare and less used; only found } \\
\text { in Chale area }\end{array}$ \\
\hline
\end{tabular}

Table 3. Summary of livelihood diagrams, resources and gears used

\begin{tabular}{|c|c|c|c|c|c|}
\hline & Gear using & Part of gear & & Reasons for & Boundary \\
\hline Resource & the resource & where used & Form used & preferred use & $\mathrm{I}^{+} \mathrm{O} \mathrm{OI}$ \\
\hline \multicolumn{6}{|c|}{ TERRESTRIAL VEGETATIONAL } \\
\hline $\begin{array}{l}\text { Minyaa } \\
\text { (Hyphaene compressa) }\end{array}$ & Basket trap & $\begin{array}{l}\text { Ties all wooden } \\
\text { strips all round }\end{array}$ & $\begin{array}{l}\text { Stripped stalks } \\
\text { and leaves }\end{array}$ & $\begin{array}{l}\text { Abundant } \\
\text { and resists water }\end{array}$ & $\sqrt{ }$ \\
\hline $\begin{array}{l}\text { Mikone } \\
\text { (Grewia vaughanii) }\end{array}$ & Spear gun & $\begin{array}{l}\text { Supportive } \\
\text { handle }\end{array}$ & Sticks & $\begin{array}{l}\text { Light and floats while } \\
\text { a fisher snorkels }\end{array}$ & $\sqrt{ }$ \\
\hline \multirow[t]{2}{*}{ Milanga } & Basket trap & Makes bottom & Wooden strips & $\begin{array}{l}\text { Slippery when wet to } \\
\text { allow fish removal }\end{array}$ & \multirow[t]{2}{*}{$\sqrt{ }$} \\
\hline & Hand spear & Handle & Sticks & Its smell attracts fish & \\
\hline $\begin{array}{l}\text { Misumari } \\
\text { (Milletia usaramensis) }\end{array}$ & Basket trap & Makes top & Wooden strips & $\begin{array}{l}\text { Hardy enough to } \\
\text { withstand storms } \\
\text { and lifting of catch }\end{array}$ & $\sqrt{ }$ \\
\hline $\begin{array}{l}\text { Mibokwe } \\
\text { (Annona senegalensis) }\end{array}$ & Spear gun & $\begin{array}{l}\text { Supportive } \\
\text { handle }\end{array}$ & Sticks & $\begin{array}{l}\text { Light and floats while } \\
\text { a fisher snorkels }\end{array}$ & $\sqrt{ }$ \\
\hline Mangrove roots & $\begin{array}{l}\text { fishing and } \\
\text { bottom-set } \\
\text { nets }\end{array}$ & As floaters & Root pieces & Lightweight & $\sqrt{ }$ \\
\hline \multicolumn{6}{|l|}{ NON-VEGETATIONAL } \\
\hline $\begin{array}{l}\text { Old bicycle tubes and } \\
\text { wires }\end{array}$ & spear gun & shooting lever & $\begin{array}{l}\text { As stripped } \\
\text { tubes and wires }\end{array}$ & Locally available & $\sqrt{ }$ \\
\hline Hooks and line & fishing line & main gear parts & $\begin{array}{l}\text { Ready-made } \\
\text { in shops }\end{array}$ & Locally available & $\sqrt{ } \sqrt{ } \sqrt{ }$ \\
\hline
\end{tabular}

+ I, Inside; O, Outside; OI, partly inside, partly outside 


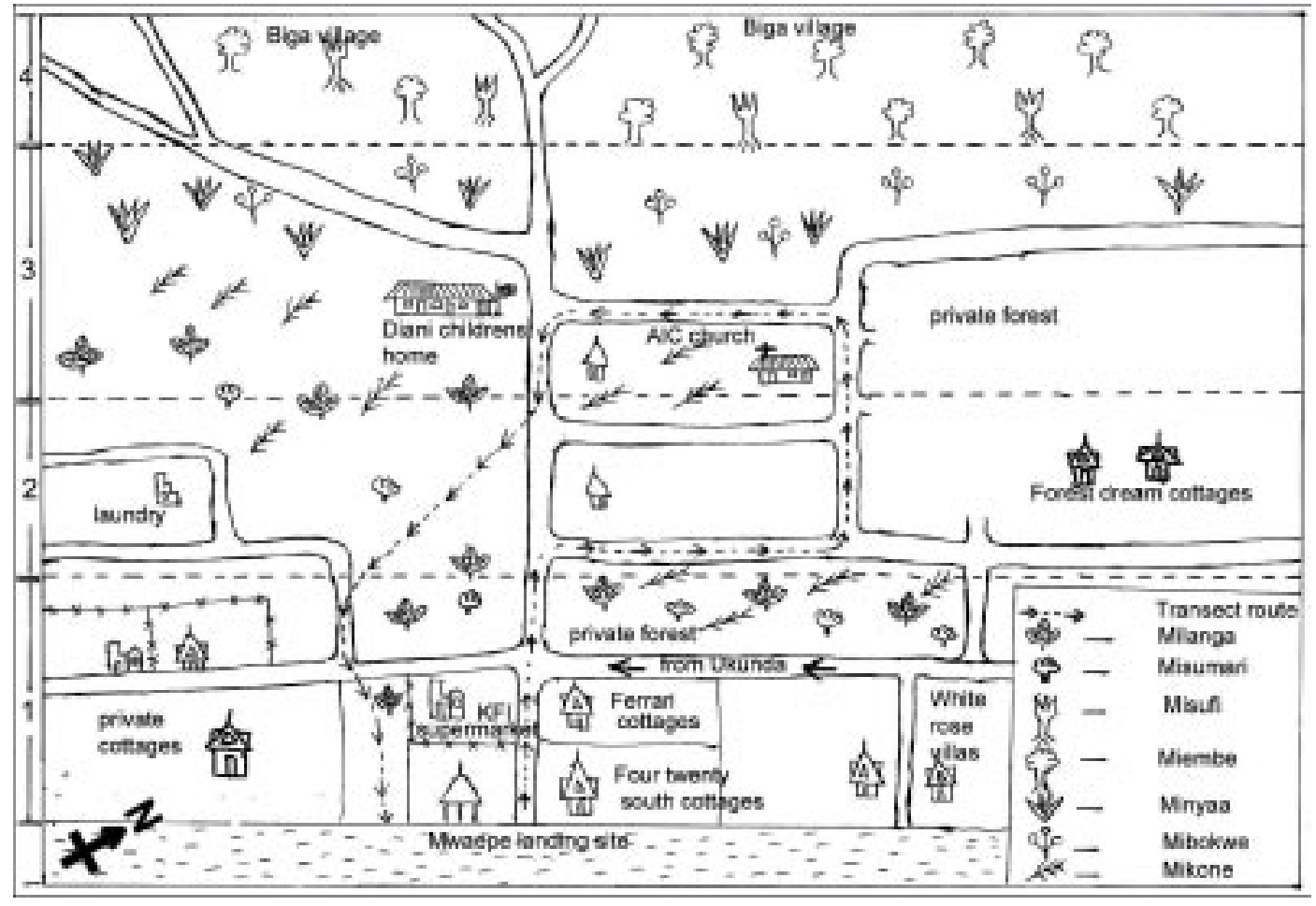

Fig. 2. Fishers' resources sketch map of the area corresponding to Mwaepe landing site. The vegetation zones $1,2,3$ and 4 are shown in the left of the map. Maps are as drawn by fisher participants, so are not drawn to scale. Arrow shows approximate north direction

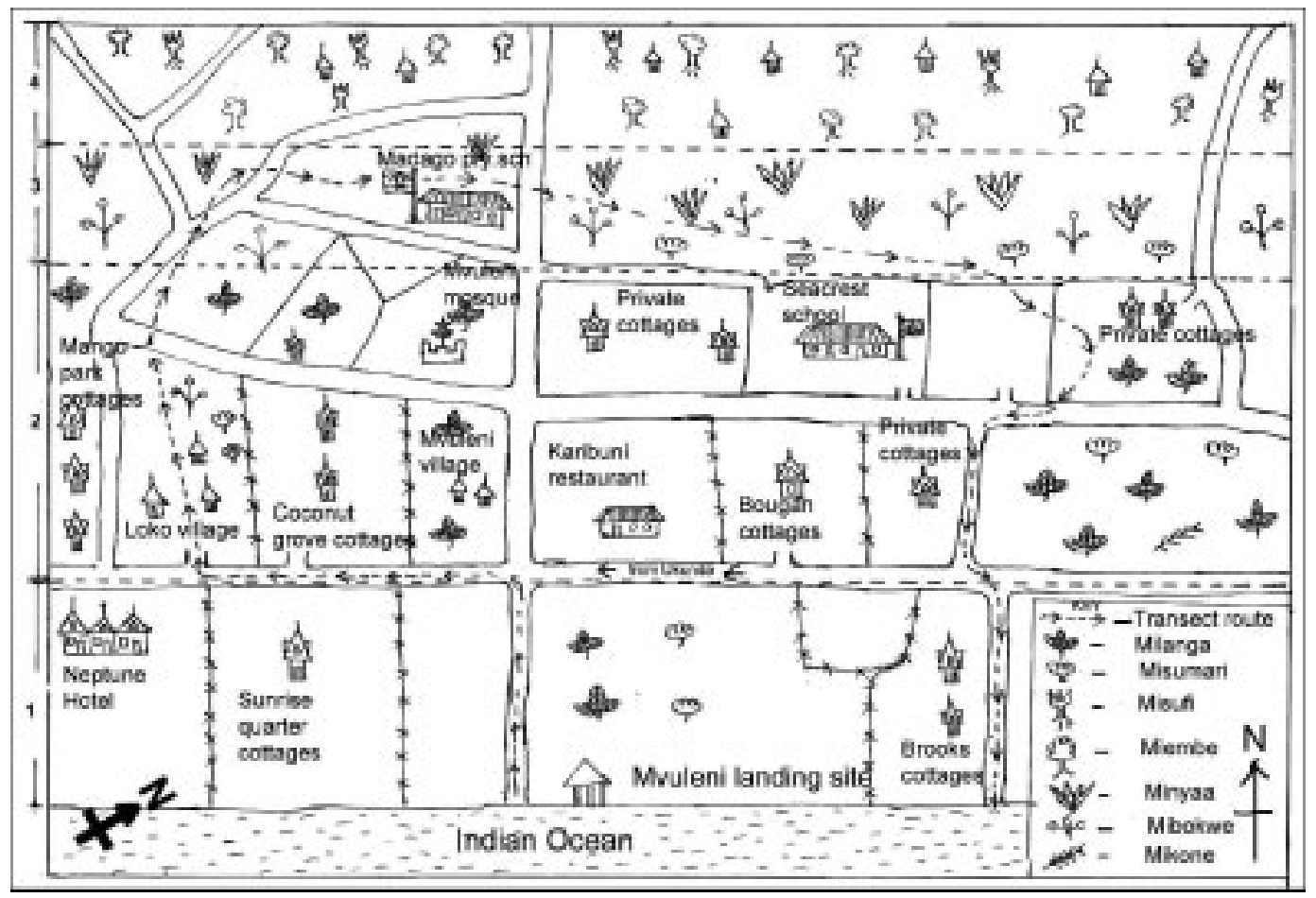

Fig. 3. Fishers resources sketch map of the area corresponding to Mvuleni landing site. Details as in Fig. 2. 


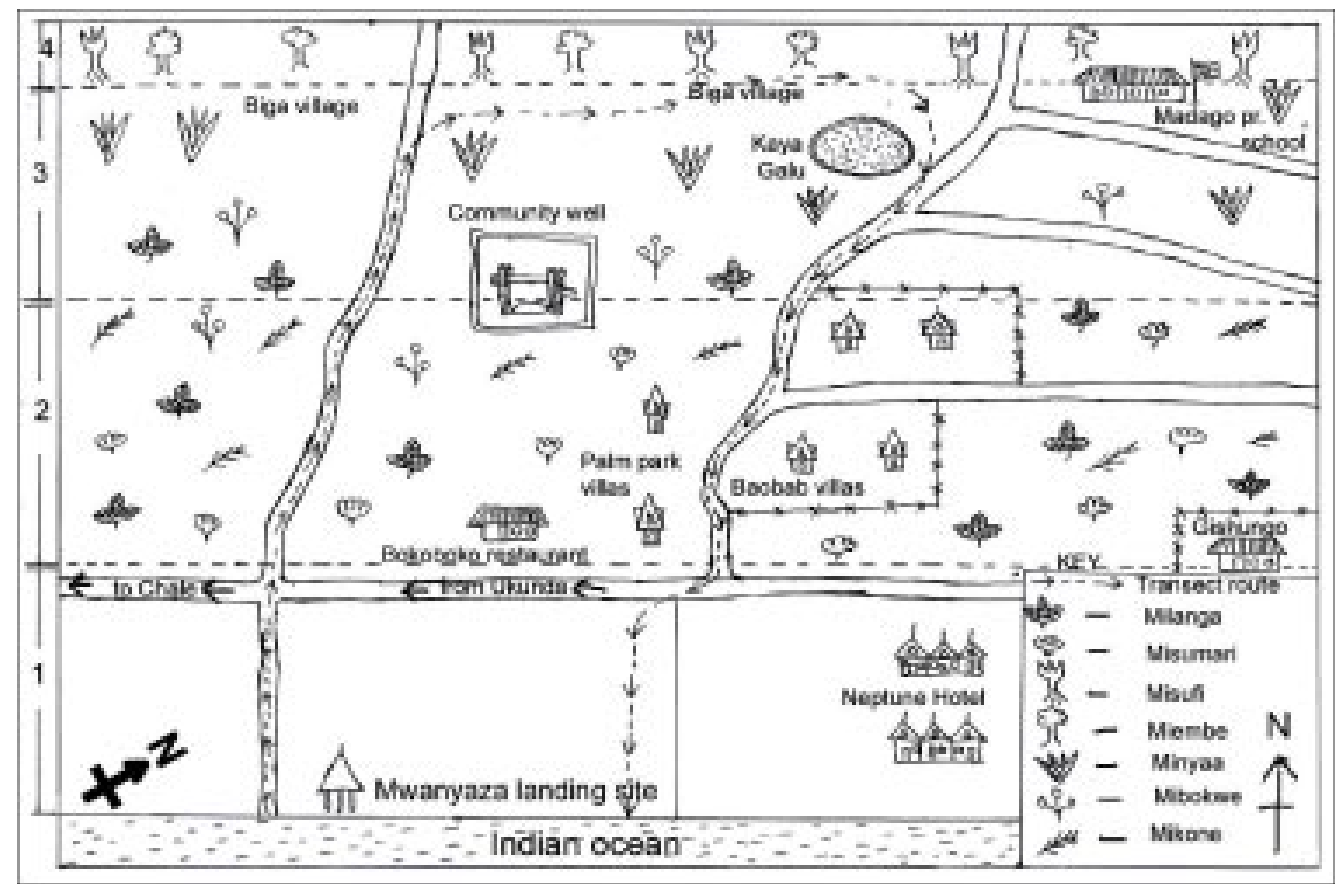

Fig. 4. Fishers resources sketch map of the area corresponding to Mwanyaza landing site. Details in Fig. 2.

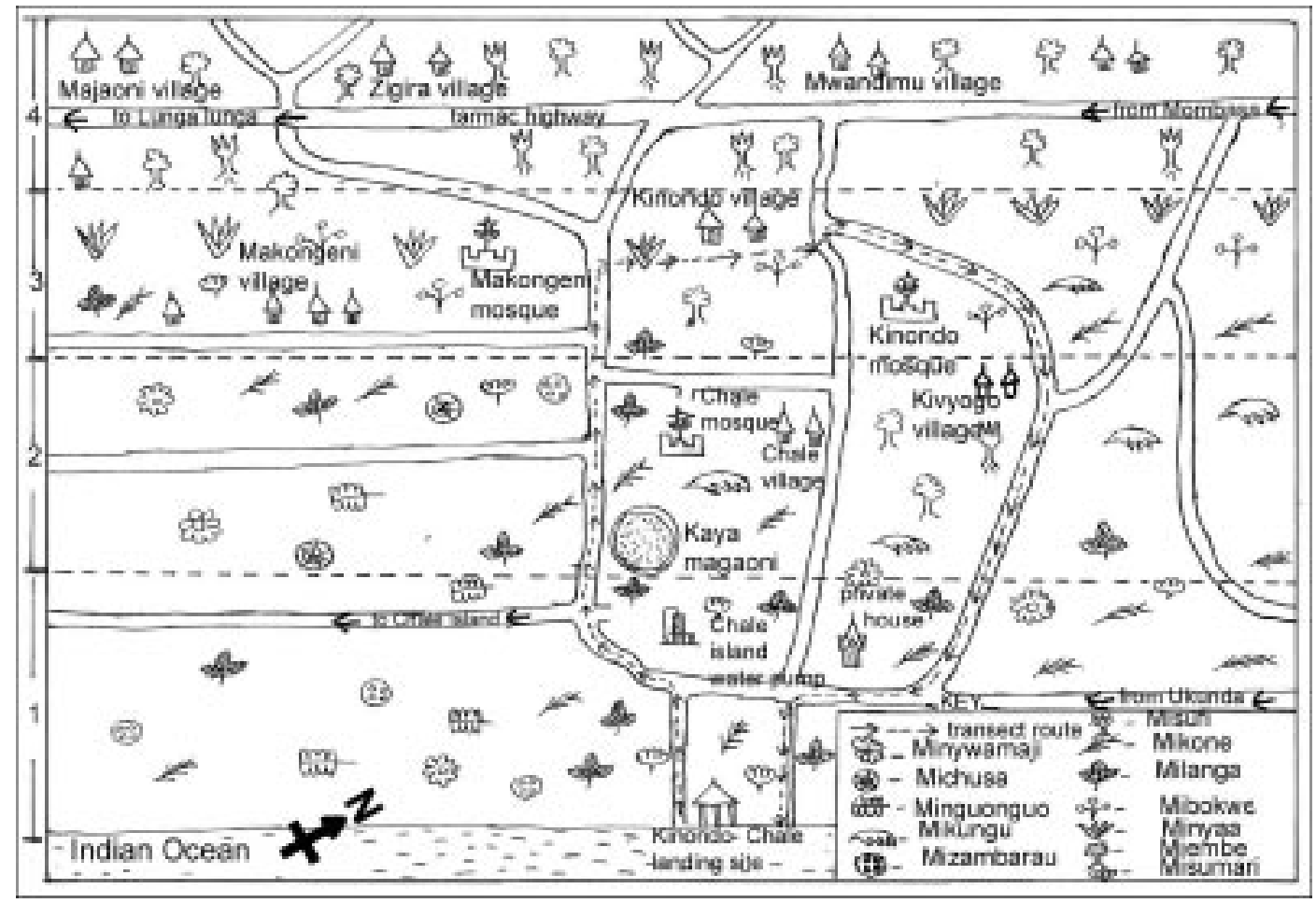

Fig. 5. Fishers' resources sketch map of the area corresponding to Kinondo-Chale landing site. Details as in Fig. 2. 
areas (Figs 2, 3, 4 and 5). In all the areas, zone 1 shows a high density of vegetation, namely trees and shrubs (Table 1). However this is in the few forest patches that exist. In many cases, these forest patches are in private beach plots and are therefore unavailable for exploitation by fishers. The relative density of vegetation decreases from zone 1 to zone 4 .

Mikone, misumari and milanga are found at the intermediate sections between the grasslands and the beach, in zones 1 and 2. Minyaa and mibokwe are found in the grassland sections in zone 3. Trees used in canoe-making are varied, with natural forest trees being found in zones 1 and 2, and trees with additional agricultural uses, such as mikungu, misufi and miembe, being found in zone 4. This typical configuration is similar in all the areas of Galu and Kinondo-Chale.

Resources for making the basket trap are in good supply over the whole study area, but are more abundant and widespread in Kinondo compared to Galu. Basket traps require milanga, misumari and minyaa: milanga and misumari are found within thickets in zones 1 and 2, while minyaa are found in the grasslands in zone 3 and encroaching into some sections of zone 4.

Stones used as weights to sink the lower parts of fishing nets and bottom set net are collected everywhere, while floats from both artificial and natural sources (such as mangrove roots) are obtained from outside the local area. Mangrove floats are obtained from neighbouring Gazi village mangrove stands, immediately to the south.

Spearguns use either mibokwe or mikone, which are used as the main shaft of the speargun. The mikone are found between zones 1 and 2, while mibokwe are found in the grasslands on zone 3 in all the areas. However mibokwe, though abundant in Kinondo-Chale, are rarely used since the preferred mikone is also abundant.

Handspears require only one terrestrial resource, namely the milanga which provides the long stick used as the spear's handle. The milanga are mainly found in zones 1 and 2 in all the areas. However the use this gear is slowly becoming unpopular because it is viewed as outdated despite being cheap and easy to make (Obura et al., 2002a).

Gears such as basket traps, handlines, bottom set net and gill nets require dugout canoes for transport. Trees used in making canoes are available within the study area, though often they are obtained from other neighbouring areas, such as Gazi. A number of tree species are used for making canoes (Table 2): mikungu, misufi and miembe trees are grown in farms amongst the coconut palms and bananas in zones 3 and 4 in Kinondo-Chale, while in Galu they are within zone 4 (Figs 2, 3, 4 and 5). Forest and thicket trees such as mizambarau, michusa, minguonguo and minywamaji are found in Kinondo, where most forests have not been fully exploited, but are rare in Galu where little natural vegetation remains, or are unavailable for use by fishers. In Kinondo misufi trees are rarely used because other preferred trees are abundant; misufi wood is relatively light and does not last for long in water. In Galu, however, it is commonly used since there are limited alternatives.

\section{Verification of resource sites}

Mwaepe (Fig. 2), the northern-most landing site in Galu, is subject to an ownership dispute between the fishers and a private owner. Here there are a few mikone and misumari shrubs that are readily accessible to fishers as they are near to the landing site. The few resources on other areas of zones 1 and 2 are on private plots owned mostly by absentee landlords. Most other resources are found slightly inland of zone 2. Fishers' resources at Mwaepe are gradually being cleared for other landuse activities, mainly construction and farming, especially on zone 2 and part of zone 3. Mwaepe's zone 3 is just a small portion of the grassland area, which has few minyaa and mibokwe, and is experiencing pressure from cultivators and cattle grazers (pers. obs.). Zone 4 covers Biga village and consists of farmland under intense agriculture.

Zones 1 and 2 of Mvuleni (Fig. 3 and Table 4) are largely occupied by private cottages. The few plots that have been left unoccupied by absentee landlords are used by fishermen to acquire the resources they need. These resources are mainly milanga, misumari and mikone. Unused plots near Mango Park Cottages provide many resources. Plots in zone 3 owned by local farmers are under fallow agriculture and hence shrubs used by fishers' are occasionally cleared to make way for cultivation. The fallow agriculture system allows 


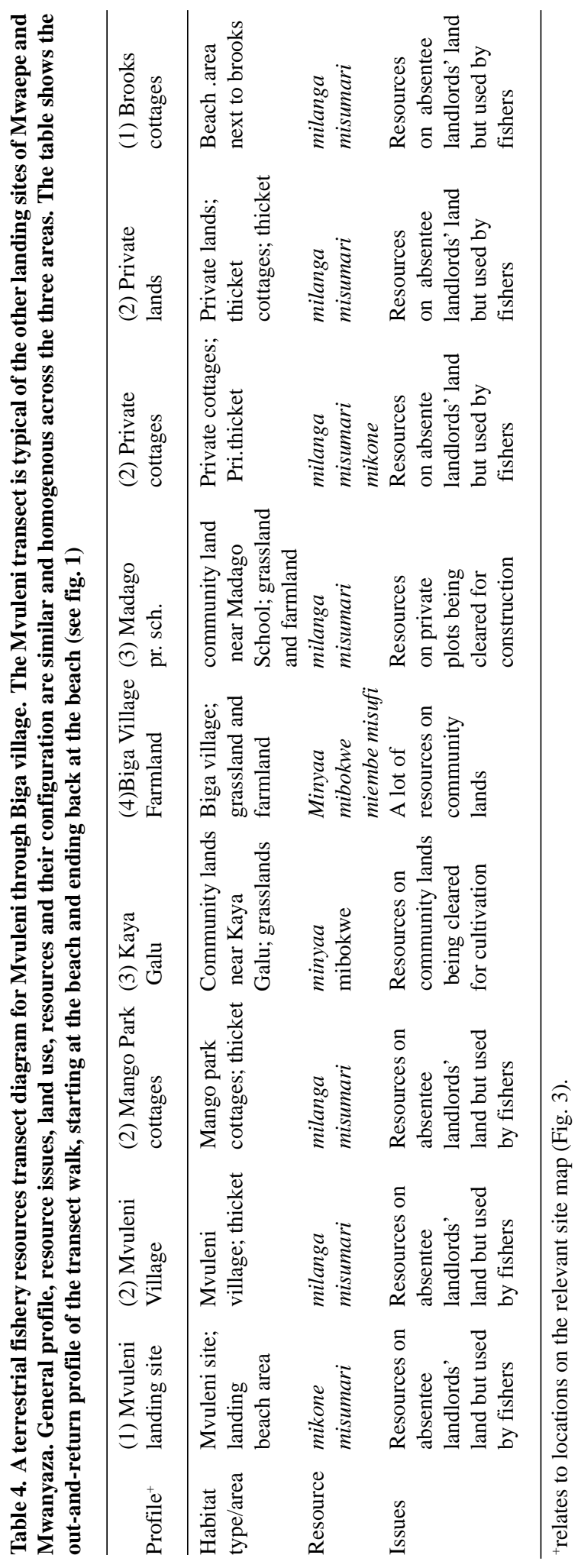

rejuvenation of the fishers' resources in the form of sprouts and coppices.

Mwanyaza landing site is the southern-most one in Galu. Like Mvuleni, it has many idle plots owned by absentee landlords, which provide opportunities for resource access to fishers. There are many resources in zone 2 where fallow agriculture has been attempted. There are fewer developments in Mwanyaza between zones 1 and 3 (Fig. 4) compared to Mvuleni and Mwaepe (Figs 2 and 3). The configuration of resources in zone 3 of Mwanyaza is different compared to the other sites. The grasslands consist of milanga and misumari amongst minyaa and mibokwe unlike in the other sites where only minyaa and mibokwe occur. Also minyaa encroach into zone 2 and alternates with mikone and milanga. This means that minyaa occupy a larger area than other resources. Like the other areas, farmlands and homesteads are in zone 4.

The Kinondo-Chale transect differed from the three Galu transects, in terms of diversity of resources, land use patterns, resource availability and the larger expanse of land with resources. On zone 1 there are many resources in the dense thickets on plots with absentee landlords (Fig. 5 and Table 5). Milanga, mikone, misumari and minywamaji are in high density. In zone 2 close to Kaya Magaoni (a sacred forest) there are rare resources like minguonguo, michusa, minywamaji and mizambarau (canoe making trees) not found in other areas. Kinondo-Chale does not have a homogenous resource configuration across the zones as compared to Galu. Instead there are few farms on the upper part of zone 2 where canoemaking trees such as mizambarau, miembe, mikungu and misufi are grown. The farms here are not permanently inhabited, but are cultivated and owned by the fishing community that lives close by at Gandikani and Chivyogo villages inland from the beach. Tenure of the farms here is guaranteed by title deeds. On the southern end past Kaya Magaoni there are mikone and misumari on fallow farmlands and as isolated patches in the farms. Mikone shrubs here are left to grow very tall compared to those in Galu since there is less pressure on them. Grasslands on zone 3 have numerous minyaa and unused mibokwe, which are less preferred to the mikone. Another section 
Table 5. Terrestrial fishery resources transect diagram for Kinondo- Chale through Makongeni and Kinondo villages. Kinondo-Chale landing site has more resources and a different configuration as compared to Galu landing sites. Issues and land use patterns are also different. Notes as in table 4.

\begin{tabular}{|c|c|c|c|c|c|c|c|c|}
\hline Profile & $\begin{array}{l}(1) \\
\text { Kinondo- } \\
\text { Chale } \\
\text { landing site }\end{array}$ & $\begin{array}{l}\text { (2) } \\
\text { Chale island } \\
\text { water pump }\end{array}$ & $\begin{array}{l}(2) \\
\text { Kaya } \\
\text { Magaoni }\end{array}$ & $\begin{array}{l}\text { (3) } \\
\text { Makongeni } \\
\text { village }\end{array}$ & $\begin{array}{l}\text { (4) } \\
\text { Kinondo } \\
\text { village }\end{array}$ & (3) & $\begin{array}{l}(2) \\
\text { Kivyogo } \\
\text { village }\end{array}$ & (1) \\
\hline $\begin{array}{l}\text { Habita } \\
\text { type/ } \\
\text { Area }\end{array}$ & $\begin{array}{l}\text { Chale } \\
\text { landing site } \\
\text { thicket }\end{array}$ & $\begin{array}{l}\text { Chale- Island } \\
\text { water pump } \\
\text { thicket }\end{array}$ & $\begin{array}{l}\text { Around } \\
\text { Kaya } \\
\text { Magaoni; } \\
\text { forest }\end{array}$ & $\begin{array}{l}\text { Makongeni } \\
\text { village; } \\
\text { farmland } \\
\text { grassland }\end{array}$ & $\begin{array}{l}\text { Kinondo } \\
\text { village; } \\
\text { farmland } \\
\text { and partly } \\
\text { grassland }\end{array}$ & $\begin{array}{l}\text { Kinondo } \\
\text { area; } \\
\text { thicket }\end{array}$ & $\begin{array}{l}\text { Kivyogo } \\
\text { village; } \\
\text { farmland }\end{array}$ & $\begin{array}{l}\text { Chale } \\
\text { beach } \\
2 \text { area; } \\
\text { thicket }\end{array}$ \\
\hline Resources & $\begin{array}{l}\text { milanga } \\
\text { misumari } \\
\text { minywamaji } \\
\text { mikone }\end{array}$ & $\begin{array}{l}\text { misumari } \\
\text { milanga } \\
\text { michusa } \\
\text { mnguonguo } \\
\text { mikone } \\
\text { minywamaji }\end{array}$ & $\begin{array}{l}\text { milanga } \\
\text { misumari } \\
\text { mikone } \\
\text { minywamaji } \\
\text { mizambarau }\end{array}$ & $\begin{array}{l}\text { minywamaji } \\
\text { miembe } \\
\text { mibokwe } \\
\text { minyaa }\end{array}$ & $\begin{array}{l}\text { minywamaji } \\
\text { miembe } \\
\text { mibokwe } \\
\text { minyaa }\end{array}$ & $\begin{array}{l}\text { misumari } \\
\text { mikone } \\
\text { milanga } \\
\text { misufi }\end{array}$ & $\begin{array}{l}\text { minywamaji } \\
\text { miembe } \\
\text { mikungu }\end{array}$ & $\begin{array}{l}\quad \text { milanga } \\
\text { misumari } \\
\text { minywamaji }\end{array}$ \\
\hline Issues & $\begin{array}{l}\text { Abundant } \\
\text { resources } \\
\text { on } \\
\text { absentee } \\
\text { landlord's } \\
\text { land but } \\
\text { used by } \\
\text { fishers }\end{array}$ & $\begin{array}{l}\text { Resources } \\
\text { on } \\
\text { absentee } \\
\text { landlord's } \\
\text { land but } \\
\text { used by } \\
\text { fishers }\end{array}$ & $\begin{array}{l}\text { Resources } \\
\text { on } \\
\text { community } \\
\text { land but } \\
\text { used by } \\
\text { fishers }\end{array}$ & $\begin{array}{l}\text { Resources } \\
\text { on } \\
\text { community } \\
\text { lands. } \\
\text { Mibokwe } \\
\text { in plenty \& } \\
\text { rarely used }\end{array}$ & $\begin{array}{l}\text { Resources } \\
\text { on } \\
\text { community } \\
\text { lands. } \\
\text { Mibokwe } \\
\text { in plenty \& } \\
\text { rarely used }\end{array}$ & $\begin{array}{l}\text { Resources } \\
\text { on } \\
\text { community } \\
\text { land but } \\
\text { used by } \\
\text { fishers }\end{array}$ & $\begin{array}{l}\text { Resources } \\
\text { on farms } \\
\text { owned by } \\
\text { local } \\
\text { individuals } \\
\text { but used } \\
\text { by fishers }\end{array}$ & $\begin{array}{l}\text { Resources } \\
\text { on absentee } \\
\text { landlords' } \\
\text { land but } \\
\text { used by } \\
\text { fishers }\end{array}$ \\
\hline
\end{tabular}

consisting of farmlands begins at the upper zone 3 to zone 4 . Kinondo-Chale has much more expansive resource areas than Galu.

\section{DISCUSSION}

Results indicate that the distribution of terrestrial resources, and their patterns of use are similar for the three landing sites in Galu (Mwaepe, Mvuleni and Mwanyaza), but different for Kinondo-Chale. Galu, to the north, is more heavily populated, and the land is largely subdivided among private landowners, compared to Kinondo, to the south, where most land parcels are still unoccupied or unutilised. These differences in population pressure and land use patterns have profound consequences on the abundance, diversity and access to terrestrial vegetation resources used by fishers. Sampling could not be conducted in the more heavily populated Diani sublocation north of Galu as permission could not be obtained from the local leaders.

\section{Resource use patterns and pressure}

Resources such as milanga, misumari and mikone used in construction of multiple gears are under constant exploitation and this can only increase with increasing population pressure. In Galu the shrub resources are are already harvested as sprouts and coppices. However, in Chale where resources are more plentiful, especially mikone which are particularly abundant, they are less heavily harvested, and grow to reasonable heights (pers. observ.). Similarly, mibokwe in KinondoChale are rarely used due to the abundance of mikone, which are the fishers' first choice for making spearguns.

The miembe (mango) trees are under heavy pressure for making canoes in Galu, while also being valuable for fruit production. A tree may be valued from around KShs 8,000 (approx US\$ 100) and upwards for canoes, while it may yield slightly less than KShs 8,000 per year from fruit production. The miembe are heavier demand in Galu than in Kinondo-Chale, because there are 
fewer alternative natural forest trees in Galu. This could prove to be a problem for mango fruit production as more miembe trees are used in canoe making. Significantly, only large mature trees are cut down for canoes and it often takes over 30 years to achieve an appropriate size.

As indicated by the livelihood diagrams, no vegetation resources within the local community boundaries are in critical short supply for making fishing gear, except for a few resources for making canoes. Therefore the fishing communities in Kinondo and Galu currently have a high degree of resource independence. The primary exception to this is the shortage of natural forest trees for making canoes in Galu, and fishers from here have decreasing options for obtaining trees for canoes and often have to go outside the local area boundary (e.g. to Gazi to the south, or further inland) to obtain suitable trees.

\section{Resource access and land ownership}

In the study area, private cottages, tourist hotels, businesses and homes heavily occupy the land in zones 1 to 3 . In particular the prime land in the northern sections within zone 1 (i.e. beach 1 and beach 2 areas, Table 1), is fully divided into private plots. There area large number of absentee landlords whose plots are not fenced, allowing unrestricted access. Thus, fishers still have access to vegetation resources on unoccupied and unfenced private plots and the situation is not critical at present. While this is positive, increasing privatization and occupation rates of plots reduces the resource base as occupation comes with vegetation clearing. The threat of this loss of resources is masked by the slower occupation compared to privatization rates, but is clearly shown in this study.

Galu has greater numbers of fishermen and privatization and occupation rates compared to Kinondo, explaining the smaller sizes and abundances of the utilized trees, shrubs and bushes. Tourism in Diani, immediately north of Galu, has differentially changed access to the sea and utilization of reef resources, showing that development has reduced the number of landing sites (Obura \& Mwaura 2001). This has also resulted in a change from the sites, indigenous names to names of the occupying hotels e.g.
Tradewinds, Reef and Diani-house (Fig 1); by contrast, Galu and Kinondo landing sites have retained their original names. Nevertheless, there is a spillover of development from Diani into Galu already affecting vegetation resource availability and access. The establishment of small private beach houses and cottage hotels in Kinondo is also affecting this region.

Mwaepe, the northern-most landing site in Galu has the lowest availability of vegetation resources and is a site of active ownership conflict, a private developer having tried to claim the whole landing site area. Mwaepe fishers have limited routes to their villages, which tend to be long and circle around private plots. Mvuleni fishers have to occasionally use private property belonging to absentee landlords to get to their homes and to vegetation resources. Mwanyaza fishers face similar problems of access, though to a lesser extent, and the land in zones $2-4$ is primarily clear or used for fallow cultivation. Kinondo-Chale is the only area without a problem of access routes at the present since most of the expansive land is unoccupied and in most cases not even subdivided.

With respect to land ownership at the community level or by villagers, the current land tenure system does not favour settled and more permanent land utilisation in the community lands due to lack of ownership rights provided under title deeds. This may change in future to a more formalised system of privatisation that will allow ownership, following broader land ownership trends in Kenya. A presidential directive over absentee landlordship and more efficient issuance of title deeds in Kwale district, on 13th of September 2003, significantly accelerated the trend towards privatization. If effected, a sudden rush to develop unoccupied land could occur, and unallocated land may be rapidly subdivided for private ownership, resulting in declining access to land and clearing of vegetation. This change in land-use patterns would drastically reduce the distribution and accessibility of vegetation resources for fishermen and lead to competition and conflict. One possible outcome of declining resources for making gear is that fishers abandon traditional gears that depend heavily on local resources (such as basket traps and stick traps, uzio) 
to use gears that can be sourced outside the local area, such as nets and handlines, or to gears that need fewer and less specialized local vegetation, such as handspears and spearguns.

\section{CONCLUSION}

This paper addresses an aspect of artisanal fisheries that is not generally considered, but may have major implications and impacts on the more classical fishery issues of declining catch, gear conflict and illegal fishing. Some potentially important corollaries of the findings presented here, with respect to broader social and land use issues in the Diani-Chale area, are outlined below.

Locally available resources have been used to make fishing gears for generations and essentially determine the type of gears used in the artisanal fishery. Conflict in the local fishery in Diani has increased progressively over the last 2 decades as a result of increased pressure, declining catch levels, immigrant fishers and their new gear and access/conservation issues (McClanahan et al., 1997; Rubens, 1996; King, 2000, Obura et al., 2001). A major focus of mitigation is to promote the use of traditional over modern gears, particularly where the latter are destructive in some way or illegal, a pattern repeated in many locations in East Africa (McClanahan et al., 1996; Church \& Obura, 2004). However progressive reductions in the availability of resources to make traditional gear may make this management option impossible, and force fishers to give up traditional gears to use more destructive modern ones. Already, young fishers preferentially use spearguns over traditional traps, partly because of the need to collect large amounts of sticks and materials to make traps, from increasingly distant locations, which they feel is too laborious and takes too much time. Therefore protection of the vital resource base of materials used in assembly of fishing gear and equipment is necessary if the long-practiced artisanal fishing is to be sustained.

On the positive side, it may be possible to reverse the problems of declining resources by cultivation and planting of young plants or alternatives. In the case of mango trees, tree nurseries can be started to encourage growing of mangoes, or of alternatives such as mikungu and misufi, which also have agro-forestry benefits to farmland and the environment. Additionally, areas with good growth of vegetation resources could be set aside for protection and sustainable utilisation by fishers, especially for vulnerable shrubs.

Acknowledgements-We would like to thank the fishermen of Mwaepe, Mvuleni, Mwanyaza and Kinondo-Chale landing sites for their cooperation and participation, which made the mapping exercise a reality. In particular, special appreciation goes to landing site chairmen, Mzee Said S. Zamu, Mzee Bakari Kitunguu, all village chairmen and Chief Mwaropia for their assistance in organising the fishers for the mapping exercise. We also thank the mapping assistants for their vision and planning abilities, and CORDIO researchers William Nyaga, Jelvas Mwaura, and Innocent Wanyonyi for their assistance throughout the study. This study was conducted under research permit MOEST/13/001/21C 242 to DO.

\section{REFERENCES}

Arquiza, Y.D., (1999) Rhythm of the sea: A coastal environmental profile of San Vincente, Palawan. Coastal Resource Management Project, Cebu City, Philippines. 131 pp.

Chapin,M. \& Threlkeld, B. (2001) Indigenous landscapes; a study in ethnocartography. Centre for the support of native lands, U.S.A. $152 \mathrm{pp.}$

Church, J.E., Obura, D.O. (2004) Management recommendations for the Kiunga Marine National Reserve, based on coral reef and fisheries catch surveys, 1998 - 2003. CORDIO/WWF KMNR, Lamu, Kenya.

Ford,R., Lelo, F. \& Rabarison, H. (1998) Linking governance and effective Resource management; A guidebook for community-based monitoring and evaluation. APAM, U.S.A. 42 pp.

Glaesel, H. (1997) Fishers, parks, and power: the socio-environmental dimensions of marine resource decline and protection of the Kenya coast. University of Wisconsin-Madison.

King, A. (2000) Managing without institutions: the role of communication networks in governing resource access and control. Ph.D. thesis. University of Warwick, UK. 251 pp.

Lelo, F., Ayieko,J., Muhia,R., Muthoka,S., Muiruri,H., Makenzi,P., Njeremani,D. \& Omollo,J. (2000) Egerton PRA field handbook for participatory appraisal practitioners. PRA Programme, Egerton University. 86 pp. 
McClanahan, T., Glaesel, H., Rubens, J. \& Kiambo, R. (1997) The effects of traditional fisheries management on fisheries yields and the coral-reef ecosystems of southern Kenya. Environmental Conservation 24(2): 105-120.

Obura, D. \& Mwaura, J. (2001) Overlap of tourism and fisheries in the Diani-Chale coral reef; opportunities for multiple use zonation. CORDIO East Africa.

Obura, D. \& Wanyonyi, I. (2001) The local geography of an artisanal fishery and its relevance to fisheries management. CORDIO East Africa.

Obura, D., Wanyonyi, I. \& Mwaura, J. (2001) Beach Seine Fishing In Galu And Kinondo SubLocations, Kenya. CORDIO East Africa, Mombasa.

Obura.D, Wanyonyi, I. \& Mwaura, J. (2002a) Participatory monitoring of an artisanal fishery in Kenya. In: Linden, O., Souter, D., Wilhelmsson,
D. \& Obura, D. (eds.) Coral reef Degradation in the Indian Ocean; status report. pp 70-82.

Obura, D. D., Wells, S., Church, J. \& Horrill, C. (2002b) Monitoring of fish and fish catches by local fishermen in Kenya and Tanzania. J. Mar. Freshw. Res. 53(2): 215-222.

Rubens, J., (1996) Analysis of the benefits and costs of marine reserve regulations at Diani, Kenya. Msc thesis, unpublished. Newcastle University, United Kingdom.

Walters, J., Maragos, J., Siar, S. \& White, A. (1998) A Participatory Coastal Resource Assessment: A handbook for Community Workers and Coastal Resource Management Project. Silliman University, Cebu City, Philippines. 113 pp.

Wamukoya, G.M. \& Situma, F.D.P., (2000) Environmental Management in Kenya: A guide to the Environmental Management and Coordination Act.1999. CREEL, Kenya. 101 pp. 